\title{
Dimensional change of impression materials for dental prothesis using different measuring methods
}

\author{
Adriano Relvas Barreira de Oliveira ${ }^{1}$, Mário Alexandre Coelho Sinhoreti ${ }^{2}$, \\ Marina Amaral ${ }^{1}$, Laís Regiane da Silva Concílio ${ }^{1}$, Rafael Pino Vitti ${ }^{1}$
}

\footnotetext{
${ }^{1}$ Universidade de Taubaté, Departamento de Odontologia, Rua dos Operários, 09, CEP: 12020-340, Taubaté, São Paulo, Brasil

${ }^{2}$ Universidade Estadual de Campinas, Departamento de Odontologia Restauradora, Avenida Limeira, 901, 13414-903, Piracicaba, São Paulo, Brasil.

e-mail: relvasrj@yahoo.com.br,sinhoreti@fop.unicamp.br, marinamaral_85@yahoo.com.br, regiane1@yahoo.com,rafapvitti@gmail.com.
}

\begin{abstract}
The aim of this study was to verify the effectiveness of alternative techniques for measuring the linear dimensional change of molds obtained by different impression materials. A stainless-steel die containing three lines was used to get the impressions. The impression materials were handled according to the manufacturers' instructions. After gelation/polymerization time, the molds $(n=12)$ were stored for 30 minutes and the lines were subsequently measured using: a microscope (Olympus Measuring Microscope STM; Olympus Optical Co) with a 30x magnification (MM, control group), a digital caliper (Mitutoyo Digimatic; Kawasaki) (DC) and digitization using a digital camera (Canon EOS Rebel 3Ti; Canon) (DI). For each mold, a mean of the length of the lines was obtained. For each impression material, the difference in the length between the metallic matrix and the mold was considered as linear dimensional change $(\%)$. The data were submitted to the non-parametric Kolmogorov-Smirnov test, followed by one-way Analysis of Variance (ANOVA) for each material, and the means were compared by the Tukey test $(\alpha=0.05)$. The DI group promoted values of dimensional accuracy without significant differences with the control group (MM), except for the putty-body condensation silicone. The DC group showed significant differences for MM and DI groups for all impression materials tested. The DI group showed to be a reliable methodology (Standard error of the mean $<10 \%$ ) to measure the linear dimensional change of all impression materials. The DI group presented molds with linear dimensional change values without significant differences with MM group, except for the putty-body addition silicone. The digitization is a reliable methodology to evaluate the linear dimensional changes of molds made with impression materials, except for the putty-body elastomeric impression materials.
\end{abstract}

Key words: Dimensional Measurement Accuracy; Dental impression materials; Microscopy

\section{INTRODUCTION}

There are many reasons for dimensional changes in a mold: polymerization contraction, loss of by-product (water or alcohol), thermal contraction by changing the temperature from the mouth to room temperature, imbibing, syneresis and/or evaporation, and incomplete elastic recovery. [1,2]

The accuracy and dimensional stability of impression materials are properties of clinical interest and of fundamental importance, since they correspond to requirements for good adaptation of prostheses or indirect restorations. [3, 4] Considering the importance of the dimensional stability of the impression material and that literature has not yet completely established the most accurate molding technique, clinical and laboratory studies comparing different impression materials and protocols are extremely relevant to assist the clinical decision of dentists. [3, 5]

Recommended by international guidelines such as ISO (International Organization for Standardization) 21563:2013 [6] and 4823:2015 [7], most of the studies evaluating the accuracy and/or dimensional stability of the impression materials use a measuring microscope [4, 8-10]. The main advantage of this method is the precision to measure the linear distance between two points in a specimen. 
Currently, the advances in image processing and analysis techniques through software have been changing the reality in several areas of Dentistry. Digitization is already widely used in studies that demand precision in the measurement of small distances, such as in radiology, [11-13] orthodontics, [14, 15] implantology, [16-21] and periodontics. [22] This technique is also used in prosthesis to evaluate the accuracy or dimensional stability of molds or gypsum casts. [23-32] This technique allows the operator quick and easy access to documentation, backup of documentation and protection against physical damage, reduction in the space required for data storage and ease of information sharing. [33]

Another faster and accessible (less expensive) option is the digital caliper, an instrument that is easy to handle and widely used in scientific study to measure micrometric distances, [34-36] even with some important disadvantages such as significantly lower accuracy $(10 \mu \mathrm{m})$ and impossibility of magnifying the image for the correct positioning of the digital caliper which impairs the standardization of readings. However, measures calculated in disagreement with ISO standards are not accepted scientifically due to the lack of regulated standardization. In addition, there are no scientific studies that evaluate the feasibility (compare) of these methodologies.

In view of the above, it is very pertinent to compare these alternative techniques for measuring dimensional change using the measuring microscope technique (regulated by ISO) as control. The objective of this study was to verify the effectiveness of techniques using the digital caliper and a digital camera + software for measuring the dimensional accuracy of molds obtained by different impression materials.

\section{MATERIAL AND METHODS}

A t-test was performed for the sample calculation to establish the minimum number of samples needed to perform the methodology (Table 1). The estimated mean of the sample and the standard deviation were obtained through data available in the scientific literature $[4,27]$. The mean of the population was acquired by the pilot test.

Table 1: Sample calculation with data obtained from the scientific literature (estimated mean) and pilot study (mean of population)

\begin{tabular}{l|c}
\hline & Values \\
\hline Estimated mean of sample & 25.20 \\
\hline Standard deviation & 0.09 \\
\hline Mean of population & 25.16 \\
\hline Power of the test & $95 \%$ \\
\hline Alpha level & 0.05 \\
\hline Sample Size & 11 \\
\hline
\end{tabular}

A stainless-steel cast (ISO 21563:2013 and ISO 4823:2015) was used to perform the moldings with elastomeric materials and alginate containing silane (Figure 1 and 2) (Table 2). The horizontal linear distances in the stainless-steel cast were measured in three different methods: group I (MM/control group) using measuring microscope (Olympus Measuring Microscope STM; Olympus Optical Co) with a 30x magnification; group II (DC) - using a digital caliper (Mitutoyo Digimatic; Kawasaki) with an accuracy of $0.01 \mathrm{~mm}$ and; group III (DI) - through digitization using a digital camera (Canon EOS Rebel 3Ti; Canon) with a $100 \mathrm{~mm}$ macro lens attached to a tripod and the distances being measured by ImageJ software (US National Institutes of Health, Bethesda Softworks; Rockville).

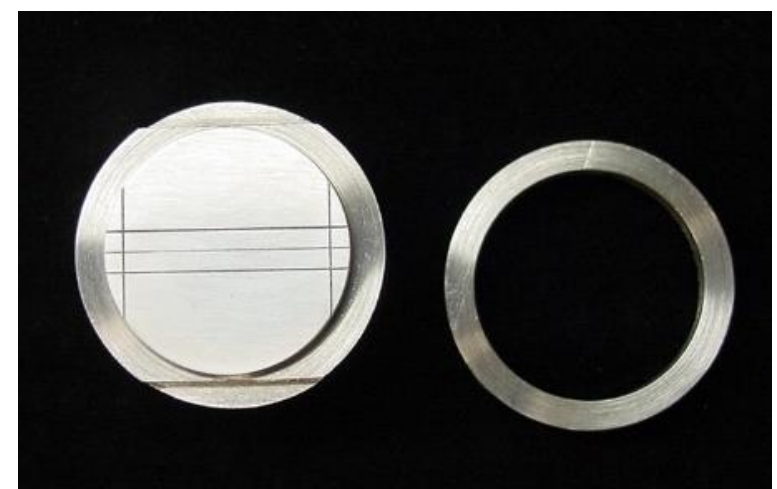

Figure 1: Stainless-steel die (ISO 21563:2013 and 4823:2015). 


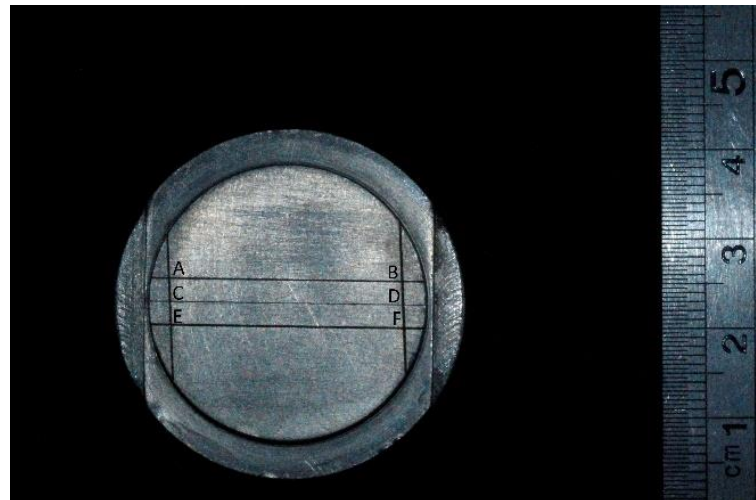

Figure 2: Stainless-steel die with scale bar. The average of the distances AB, CD and EF represents the horizontal linear distance.

Table 2: Impression materials and chemical composition.

\begin{tabular}{|c|c|}
\hline IMPRESSION MATERIAL & COMPOSITION \\
\hline $\begin{array}{l}\text { Hidrogum 5, Zhermack } \\
\text { Lot: } 0000298841 \\
\text { Exp: } 08 / 2019\end{array}$ & $\begin{array}{l}\text { Potassium alginate, diatomaceous earth, calcium sulfate, } \\
\text { trisodium phosphate and triaminofunctional silane. }{ }^{\dagger}\end{array}$ \\
\hline $\begin{array}{l}\text { Zetaplus / Oranwash L, Zhermack } \\
\text { Lot: } 279909 \text { (light-body) } \\
\quad 276074 \text { (putty-body) } \\
\text { Exp: } 04 / 2020\end{array}$ & $\begin{array}{l}\text { Base paste: polydimethylsiloxane-based silicone polymers with } \\
\text { hydroxyl terminal groups, fillers (silica and others) and } \\
\text { pigments } \\
\text { Catalytic paste: pigment, mineral oil, filler and hardener. * }\end{array}$ \\
\hline $\begin{array}{l}\text { Impregum Soft, 3M Dental Products } \\
\text { Lot: } 623378 \\
\text { Exp: } 10 / 2019\end{array}$ & $\begin{array}{l}\text { Polymer of polyether, triglycerides of fatty acids, dibenzyl } \\
\text { toluene, pigments, sulfonamide, polyethylenepolypropylene } \\
\text { glycol and filler (diatomaceous earth). * }\end{array}$ \\
\hline $\begin{array}{l}\text { Futura AD Light / Putty, DFL Industry and Commerce } \\
\text { Ltda. } \\
\text { Lot:17110791 (light-body) } \\
\text { Lot:17120876(putty-body) } \\
\text { Exp: } 12 / 2019\end{array}$ & $\begin{array}{l}\text { Polyvinylsiloxane, silicon dioxide, hydrocarbon, } \\
\text { methylhydrogenosiloxane, dyes and organoplatinum complex. }\end{array}$ \\
\hline
\end{tabular}

†[35]. *[36]. "Manufacturer

The impression materials were handled according to the manufacturer's instructions. [2, 4, 5, 8] A glass plate was used to standardize the applied pressure and allow the excess of impression material to overflow. The stainless-steel die and the glass plate were disinfected with $92.8 \%$ ethyl alcohol after each molding and a period of 5 minutes was waited for total evaporation. The molding procedures were performed in a room with controlled temperature $\left(25 \pm 2^{\circ} \mathrm{C}\right)$. After full set of the materials, the samples were stored for $30 \mathrm{~min}$ at $25^{\circ} \mathrm{C}( \pm$ $2^{\circ} \mathrm{C}$ ). The irreversible hydrocolloid molds were kept in an airtight container with $100 \%$ relative humidity and the elastomeric molds in a dried and airtight container. Careful visual inspection was performed by discarding any defective mold, such as pores, bubbles, tears or absence of material that would interfere with the reading of any of the lines.

After the storage period, the 36 specimens prepared from each impression material were divided into three groups $(\mathrm{n}=12)$ : MM, DI and DC. A previously calibrated examiner performed three length readings on each of the three lines using the three measurement methods.

In this way, an average was obtained by each specimen. Initially, the data obtained were submitted to the non-parametric Kolmogorov-Smirnov test to verify the homogeneity of the values. Then, the data were statistically analyzed by one-way Analysis of Variance (ANOVA) (line length), and the means were compared by the Tukey test $(\alpha=0.05)$. The standard error of the mean (SEM) was calculated for the groups that did not present significant difference with the MM group, according to the formula: $S E M=s / \sqrt{ }$; where $\mathrm{s}=$ standard deviation of the sample and $\mathrm{n}=$ sample size. For these groups, in each impression material, the data were also submitted to the one-way ANOVA test (linear dimensional change mold-matrix) and the means compared by the Tukey test $(\alpha=0.05)$. 


\section{RESULTS}

The digital caliper (DC) showed significant differences in the average length of the lines between all groups (MM and DI) for all impression materials evaluated $(\rho<0.01)$. The results showed that the measurement of the lines by digitization (DI) promoted values with no statistical differences with the control group (MM) for five of six groups evaluated ( $\rho>0.05)$, except for the putty-body condensation silicone $(\rho<0.01)$. (Table 3$)$.

Table 3: Averages of the length of the lines ( $\mathrm{mm})$ among the different impression materials and evaluation methods.

\begin{tabular}{c|c|c|c}
\hline & MM & DC & DI \\
\hline Condensation Silicone - putty consistency & $24.74( \pm 0.02) \mathrm{A}$ & $25.45( \pm 0.08) \mathrm{C}$ & $24.87( \pm 0.10) \mathrm{B}$ \\
\hline Condensation Silicone - light consistency & $24.74( \pm 0.05) \mathrm{A}$ & $25.46( \pm 0.09) \mathrm{B}$ & $24.68( \pm 0.14) \mathrm{A}$ \\
\hline Addition Silicone - putty consistency & $24.78( \pm 0.01) \mathrm{A}$ & $25.50( \pm 0.10) \mathrm{B}$ & $24.85( \pm 0.11) \mathrm{A}$ \\
\hline Addition Silicone - light consistency & $24.75( \pm 0.08) \mathrm{A}$ & $25.41( \pm 0.09) \mathrm{B}$ & $24.80( \pm 0.07) \mathrm{A}$ \\
\hline Polyether & $24.81( \pm 0.04) \mathrm{A}$ & $25.54( \pm 0.07) \mathrm{B}$ & $24.77( \pm 0.07) \mathrm{A}$ \\
\hline Alginate & $24.66( \pm 0.06) \mathrm{A}$ & $25.55( \pm 0.09) \mathrm{B}$ & $24.66( \pm 0.10) \mathrm{A}$ \\
\hline
\end{tabular}

Different in-line letters indicate statistical differences between the evaluation methods $(\rho<0.05)$.

The standard error of the mean (SEM) determines how precisely the sample mean estimates the population mean. A lower value of the standard error of the mean indicates a more accurate estimate of the population mean. The impression materials in DI group that presented average line lengths similar to the MM group were submitted to SEM. All materials presented SEM values below 10\%, proving their precision. (Table 4).

Table 4: SEM (\%) between the measure microscopy and digitization groups.

\begin{tabular}{l|c}
\hline MM x DI & \% \\
\hline Condensation silicone - light & 4.6 \\
\hline Addition silicone - putty & 3.5 \\
\hline Addition silicone - light & 3.6 \\
\hline Polyether & 2.9 \\
\hline Alginate & 2.8 \\
\hline
\end{tabular}

Table 5 presents the values of linear dimensional change comparing the stainless-steel die to the molds for DI and MM groups. The group DI presented molds with values of linear dimensional change without statistical differences with the MM group for all impression materials $(\rho>0.05)$, except putty-body addition silicone $(\rho<0.01)$.

Table 5: Linear dimensional change (\%) of the impression materials evaluated in measuring microscopy and digitization.

\begin{tabular}{c|c|c|c}
\hline & MM (\%) & DI (\%) & P \\
\hline Condensation silicone - light & 0.18 & 0.24 & 0.1245 \\
\hline Addition silicone - putty & 0.02 & 0.45 & $<0.01$ \\
\hline Addition silicone - light & 0.17 & 0.22 & 0.8082 \\
\hline Polyether & 0.09 & 0.13 & 0.2401 \\
\hline Alginate & 0.53 & 0.32 & 0.2494 \\
\hline
\end{tabular}

\section{DISCUSSION}

The results of the present study showed that the putty-body condensation silicone and the putty-body addition silicone presented significant difference between the measurements made using the digitization of the images and measuring microscopy, while the other materials showed no difference, and that all measurements obtained from the use of the digital caliper were statistically different when obtained through measuring microscope.

ISO 21563:2013 [6] and ISO 4823:2015 [7] guidelines recommend evaluating the linear dimensional change. However, in this study at first it was evaluated the dimensional accuracy (difference of the average of the length of the lines between metallic matrix and molds), isolating other factors in order to validate 
accurately the results (table 3). The simple verification of the dimensional change could show similar percentage results starting from different linear measurements (change mold-matrix). The exclusion of groups that showed statistical difference in the length of the lines and the dimensional stability test of only those that did not show differences allowed an accurate result (Table 5).

The digital caliper is an instrument of easy handling and low cost but presents some disadvantages that contributed to the result of the study. The impossibility for the naked eye to position the fixed and movable tips of the caliper exactly at the reference positions (Figures 3 and 4), the difficulty to keep the fixed tip stationary during the scrolling of the impeller until the movable tip reaches the final reference for measurement and physical damages that this technique can cause in the specimens were limiting factors of the technique. The results of the present study demonstrate that the use of the caliper can interfere in the results of studies that have evaluated the stability and/or dimensional accuracy of impression materials, [3941] or measured small distances, as in the areas of radiology, [34, 42] orthodontics, [43-45] dental implantology [35, 47] and periodontics. [47, 48]

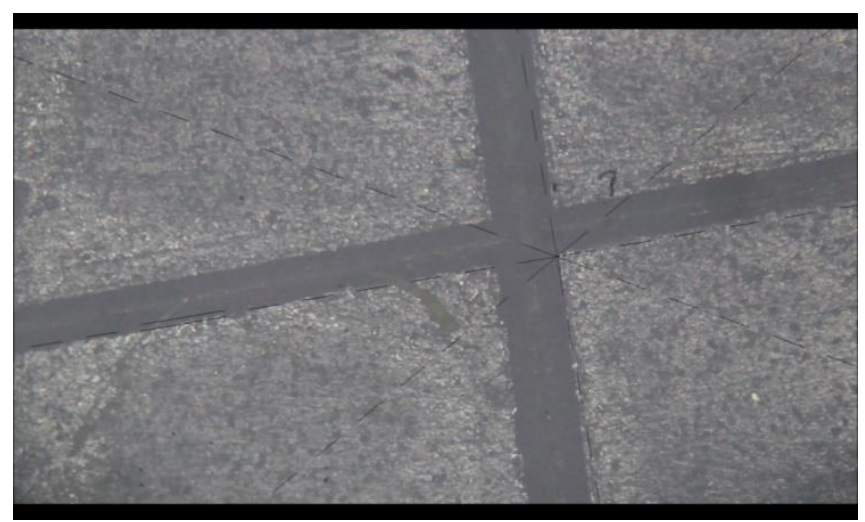

Figure 3: Reference position in the measurement by measuring microscopy.

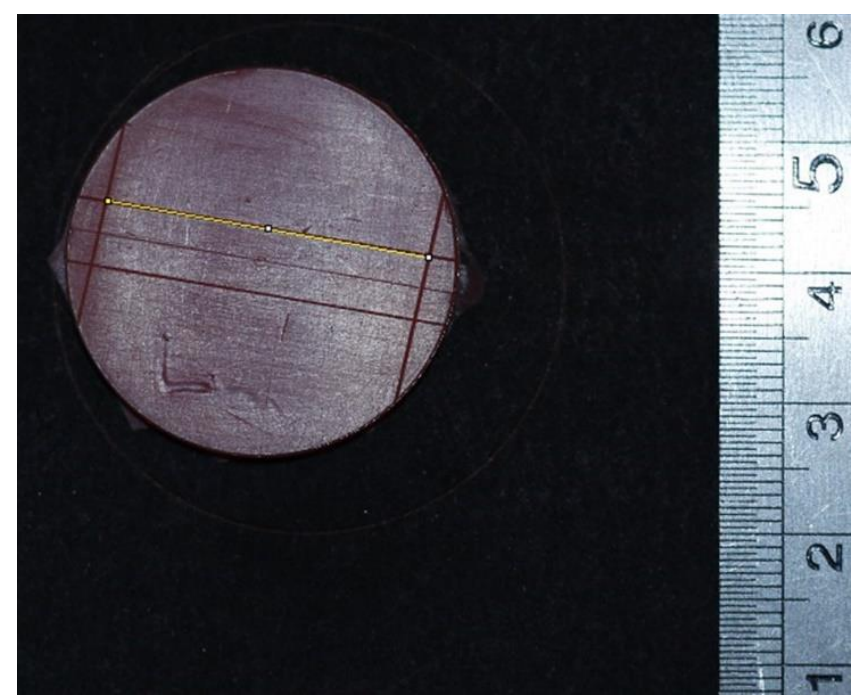

Figure 4: Reference position in software measurement.

The use of digitalized images for measurement of distances using a software presents some advantages with respect to measuring microscope that must be emphasized, such as the lower operating cost, the possibility of storing the images for the measurements at any time desired by the operator and the reduction of the average time required to measure distances.

However, there are difficulties in reading the lines in the molds made with less precise impression materials. These setbacks probably justify the results found in the present study, where the measurement of the linear dimensional change of molds by digital means was similar to measuring microscopy, except for the elastomers in putty viscosity. The by-product (alcohol) generated during the condensation polymerization process, $[1,49,50]$ as well as the lower flowability and accuracy of high viscosity impression materials, [51] 
are factors that compromise the accuracy and dimensional stability of the molds [1, 51] and may have interfered in the process of reading the lines in the putty consistency elastomeric molds. It is worth noting that the poor result obtained from the test using putty consistency may interfere with the satisfactory result of the light body, since the putty consistency is never used in clinic separately (1-step putty/light-body technique or 2-step putty/light-body technique). For this reason, the ISO presents varied protocols according to viscosity.

Alginate, although considered a low precision impression material, did not present a significant difference between the DI and MM groups. This result can be explained by the alginate (Hydrogum 5, Zhermack) used in the present study, which, for containing silane in its composition, unlike conventional alginates, has high dimensional accuracy and stability if the molds are correctly stored in temperature and relative humidity $[41,52]$ to avoid distortions. This type of alginate is considered as golden standard, so studies using conventional alginates would be needed.

In addition, alginate has a lower viscosity than putty consistency elastomers and biases that compromise the stability of alginate molds (syneresis, imbibition and evaporation) can be controlled by the operator. [37, 53, 54] However, the release of the alcohol (by-product) that occurs during the polymerization of the condensation silicone is uncontrollable. [1, 49, 50]

Some studies that evaluate the accuracy and dimensional stability of impression materials, [23-32] as well as studies in other areas of dentistry, [11-22, 55] using the digitization and software in its methodologies present a diversification of equipment. The quality of the image and the accuracy of the measurement by the software is directly related to the resolution of the image obtained from the camera. [56] Therefore, the use of digital cameras with higher resolutions can minimize limitations encountered, during the digitization. In addition, different results can be found because of the numerous equipment (cameras and softwares) available on the market and, to obtain accurate and comparable results, standardization is indispensable. [5]

Although the present study has used photography as a means of digitalizing images for linear dimensional change assessment, there are other precise methods for this procedure, such as Computer Aided Design (CAD), which allow the three-dimensional digitization of the samples. However, there are difficulties in reading irregular surfaces on impression materials such as the crest of the ridge and palate regions by the $\mathrm{CAD} / \mathrm{CAM}$ technique. This inaccuracy can be reduced using an antiglare spray with average particles size of $2.8 \mu \mathrm{m}$ which did not produce any significant negative outcome. $[33,57]$

Besides the digitization methodology did not present results with significant differences with the measuring microscopy (except for the putty body condensation silicone), the SEM was applied to reveal the accuracy of these data and indicated that the digitization is a reliable methodology because it presents lower SEM values to $10 \%$ of the length of lines (Table 4). In this study, the results showed that both MM and DI groups presented linear dimensional change less than $0.6 \%$ (Table 5), below the maximum values of change $(1.0 \%$ and $1.5 \%)$ that ISO 21563:2013 and ISO 4823:2015 recommend, respectively, using the methodology employed by it and repeated in the present study. Dimensional change values greater than 1.0\% (alginate) and $1.5 \%$ (elastomers) would indicate problems in the digitization methodology, since commercial impression materials were used in the present study, which follow ISO regulations and all variables that may interfere with the reading of the dimensional change were controlled.

However, the data in Table 5 again show that the viscosity of the impression material is a limiting factor of the digital measurement technique, since the linear dimensional change value, although within the maximum allowed (ISO 4823:2015), differs statistically from the control group (MM). This result shows that the digitization methodology can be used only to compare the dimensional change of different putty viscosity elastomers, but not to quantify the accuracy and/or dimensional stability of such impression materials.

\section{CONCLUSION}

According to the results of the present study, it can be concluded that the digital caliper is not a reliable methodology to evaluate the dimensional accuracy of molds. The digitization of irreversible hydrocolloid and light consistence elastomeric molds is a precise method to evaluate the dimensional alteration, since they presented results similar to those obtained when using the technique recommended by ISO. The flow and the by-product formed after the polymerization of the molding materials can interfere with the effectiveness of digitalization in reading the dimensional accuracy of molds.

\section{BIBLIOGRAPHY}

[1] ANUSAVICE K.J., SHEN C., RAWLS H.R., Phillips - Materiais Dentários, 12ed. Rio de Janeiro, RJ, Elsevier, 2013. 
[2] KUMARI, N., NANDEESHWAR, D.B., "The dimensional accuracy of polyvinyl siloxane impression materials using two different impression techniques: An in vitro study", The J Indian Prosthodont Soc, v. 15, pp. 211-217, 2015.

[3] VARVARA, G., MURMURA, G., SINJARI, B., "Evaluation of defects in surface detail for monophase, 2-phase, and 3-phase impression techniques. An in vitro study", J Prosthet Dent, v. 113, pp. 108-113, 2015.

[4] VITTI, R.P., SILVA, M.A.B., SINHORETI, M.A.C., "Dimensional accuracy of stone casts Made by silicone-based impression materials and three impression techniques”, Braz Dent J, v. 24, pp. 498-502, 2013. [5] NAUMOVSKI, B., KAPUSHEVSKA, B., "Dimensional Stability and Acuracy of Silicone - Based Impression Materials Using Different Impression Techniques - A Literature Review”, Pril (Makedon Akad Nauk Umet Odd Med Nauki), v. 38, pp. 131-138, 2017.

[6] International Organization for Standardization. Dental alginate impression material. $\mathrm{N}^{\circ}$ 21563:2013. [7] International Organization for Standardization. Dentistry — Elastomeric impression materials. $\mathrm{N}^{\circ}$ 4823:2015.

[8] NISSAN, J., LAUFER, B.Z., BROSH, T., “Accuracy of three polyvinyl siloxane putty-wash impression techniques", J Prosthet Dent, v. 83, pp. 161-165, 2000.

[9] BREEDING, L.C., DIXON, D.L., "Accuracy of casts generated from dual-arch impressions", J Prosthet Dent, v. 84, pp. 403-407, 2000.

[10] KULKARNI, M.M., THOMBARE, R.U., "Dimensional changes of alginate dental impression materials - An in vitro study", J Clin Diagn Res, v. 9, pp. 98-102, 2015.

[11] LANGLOIS, C.O., SAMPAIO, M.C.C., SILVA, A.E.R., et al., "Accuracy of linear measurements before and after digitizing periapical and panoramic radiography images”, Braz Dent J, v. 22, pp. 4040-409, 2011.

[12] ONO, E., FILHO, E.M., LEITE, H.F., "Evaluation of simulated external root resorptions with digital radiography and digital subtraction radiography”, Am J Orthod Dentofacial Orthop, v. 139, pp. 324-333, 2011.

[13] VAZQUEZ, L., NIZAMALDIN, Y., COMBESCURE, C., “Accuracy of vertical height measurements on direct digital panoramic radiographs using posterior mandibular implants and metal balls as reference objects", Dentomaxillofac Radiol, v. 42, pp. 20110429, 2013.

[14] YANG, L., LI, F., CAO, M., "Quantitative evaluation of maxillary interradicular bone with cone-beam computed tomography for bicortical placement of orthodontic mini-implants", Am J Orthod Dentofacial Orthop, v. 147, pp. 725-737, 2015.

[15] PADMAPRABHA, B.P., PONNAMBATHAYIL, S.A., AYNIPULLY, H., "A Precise Method of Measuring Simultaneous Intrusion and Uprighting of Mandibular Molar Using Denta Scan - A Case Report", J Clin Diagn Res, v. 9, pp. ZD01, 2015.

[16] JEMT, T., HJALMARSSON, L., "In Vitro Measurements of Precision of Fit of Implant- Supported Frameworks. A Comparison between "Virtual" and "Physical" Assessments of Fit Using Two Different Techniques of Measurements”, Clin Implant Dent Relat Res, v.14, pp. e175-e182, 2012.

[17] SIERRAALTA, M., VIVAS, J.L., RAZZOOG, M.E., "Precision of fit of titanium and cast implant frameworks using a new matching formula", Int J Dent, v. 2012, p. 374315, 2012.

[18] BERGIN, J.M., RUBENSTEIN, J.E., MANCL, L., “An in vitro comparison of photogrammetric and conventional complete-arch implant impression techniques”, J Prosthet Dent, v. 110, pp. 243-251, 2013.

[19] GIMÉNEZ B., PRADÍES G., MARTÍNEZ-RUS F., “Accuracy of two digital implant impression systems based on confocal microscopy with variations in customized software and clinical parameters", Int J Oral Maxillofac Implants, v. 30, pp. 56-64 2015.

[20] DI FIORE, A., MENEGHELLO, R., SAVIO, G., "In Vitro Implant Impression Accuracy Using a New Photopolymerizing SDR Splinting Material”, Clin Implant Dent Relat Res, v. 17, pp. e721-9, 2015.

[21] BRATOS, M., BERGIN, J.M., RUBENSTEIN, J.E., "Effect of simulated intraoral variables on the accuracy of a photogrammetric imaging technique for complete-arch implant prostheses", J Prosthet Dent, v. 2017, pp. 1-10, 2017.

[22] PREUS, H.R., TORGERSEN, G.R., KOLDSLAND, O.C., “A new digital tool for radiographic bone level measurements in longitudinal studies”, BMC Oral Health, v. 15, pp. 107-113, 2015.

[23] BROSKY, M.E., PESUN, I.J., LOWDER, P.D., "Laser digitization of casts to determine the effect of tray selection and cast formation technique on accuracy”, J Prosthet Dent, v. 87, pp. 204-209, 2002.

[24] CHEN, S.Y., LIANG, W.M., CHEN, F.N., "Factors affecting the accuracy of elastomeric impression materials", J Dent, v. 32, pp. 603-609, 2004.

[25] SHAH, S., SUNDARAM, G., BARTLETT, D., "The use of a 3D laser scanner using superimpositional software to assess the accuracy of impression techniques", J Dent, v. 32, pp. 653-658, 2004. 
[26] FARIA, A.C., RODRIGUES, R.C., MACEDO, A.P., “Accuracy of stone casts obtained by different impression materials”, Braz Oral Res, v. 22, pp. 293-298, 2008.

[27] CAPUTI, S., VARVARA, G., "Dimensional accuracy of resultant casts made by a monophase, one-step and two-step, and a novel two-step putty/lightbody impression technique: an in vitro study", J Prosthet Dent, v. 99, pp. 274-281, 2008.

[28] PANT, R., JUSZCZYK, A.S., CLARK, R.K.F., "Long-term dimensional stability and reproduction of surface detail of four polyvinyl siloxane duplicating materials”, J Dent, v. 36, pp. 456-461, 2008.

[29] GARROFÉ, A.B., FERRARI, B.A., PICCA, M., "Linear dimensional stability of elastomeric impression materials over time", Acta Odontol Latinoam, v. 24, pp. 289-294, 2011.

[30] DUGAL, R., RAILKAR, B., MUSANI, S., "Comparative evaluation of dimensional accuracy of different polyvinyl siloxane putty-wash impression techniques-in vitro study", J Int Oral Health, v. 5, pp. 8594, 2013.

[31] LEÃO, M.P., PINTO, C.P., SPONCHIADO, A.P., "Dimensional stability of a novel polyvinyl siloxane impression technique", Braz J Oral Sci, v. 13, pp. 118-123, 2014.

[32] SAYED, M.E., SAYED, M.E., AL-MAKRAMANI, B.M., "Effect of Intermixing Brands on the Dimensional Accuracy of Master Cast using Putty-wash Impression Technique", J Contemp Dent Pract, v. 17, pp. 734-739, 2016.

[33] CAMARDELLA, L.T., SOUZA, J.M.D., VILELLA, B.D.S., “Avaliação da acurácia e confiabilidade de modelos digitais por escaneamento do modelo de gesso", Ortodontia SPO, v. 47, pp. 553-559, 2014.

[34] CHAGAS, C.A.A., GUTFITEN-SCHLESINGER, G., LEITE, T.F.O., “Anatomical and radiological aspects of the supratrochlear foramen in Brazilians", J Clin Diagn Res, v. 10, pp. 10-13, 2016.

[35] LOPS, D., STELLINI, E., SBRICOLI, L., "Influence of abutment material on peri-implant soft tissues in anterior areas with thin gingival biotype: a multicentric prospective study", Clin Oral Impl Res, v. X, pp. 1-6, 2016.

[36] ADELIPOUR, M., ALLAMEH, A., TAVANGAR, S.M., "Inhibition of breast tumor growth and abnormal angiogenesis in mice treated with endothelial cells and their progenitor mesenchymal stem cells derived from bone marrow", Neoplasma, v. 63, pp. 911-924, 2016.

[37] RODRIGUES, S.B., AUGUSTO, C.R., LEITUNE, V.C., "Influence of delayed pouring on irreversible hydrocolloid properties”, Braz Oral Res, v. 26, pp. 404-409, 2012.

[38] FONSECA, R.B., BRANCO, C.A., HAITER-NETO, F., et al., "Radiodensity evaluation of dental impression materials in comparison to tooth structures”, J Appl Oral Sci, v. 18, pp. 467-476, 2010.

[39] LARSON, T.D., NIELSEN, M.A., BRACKETT, W.W., "The accuracy of dual-arch impressions: a pilot study", J Prosthet Dent, v. 87, pp. 625-627, 2002.

[40] RAD, F.H., GHAFFARI, T., SAFAVI, S.H., "In vitro evaluation of dimensional stability of alginate impressions after disinfection by spray and immersion methods", J Dent Res Dent Clin Dent Prospects, v. 4, pp. 130, 2010.

[41] ROHANIAN, A., SHABESTARI, G.O., ZEIGHAMI, S., "Effect of storage time of extended-pour and conventional alginate impressions on dimensional accuracy of casts", J Dent (Tehran), v. 11, pp. 655, 2014 [42] GARCÍA-SANZ, V., BELLOT-ARCÍS, C., HERNÁNDEZ, V., “Accuracy and Reliability of ConeBeam Computed Tomography for Linear and Volumetric Mandibular Condyle Measurements”, A Human Cadaver Study Sci, v. 7, pp. 11993, 2017.

[43] JANSON, G., VALARELLI, D.P., RIZZO, M., "Prevalence of extraction space reopening in different orthodontic treatment protocols", Am J Orthod Dentofacial Orthop, v. 152, pp. 320-326, 2017.

[44] ZHANG, D., WANG, L.C., ZHOU, Y.H., "Precision of three-dimensional printed brackets", Beijing Da Xue Xue Bao Yi Xue Ban, v. 49, pp. 704-708, 2017.

[45] MACK, S., BONILLA, T., ENGLISH, J.D., “Accuracy of 3-dimensional curvilinear measurements on digital models with intraoral scanners”, Am J Orthod Dentofacial Orthop, v. 152, pp. 420-425, 2017.

[46] KIM, S., KANG, S.R., PARK, H.J., "Quantitative measurement of peri-implant bone defects using optical coherence tomography”, J Periodontal Implant Sci, v. 48, pp. 84-91, 2018.

[47] AHMED, A.J., NICHANI, A.S., VENUGOPAL, R., “An Evaluation of the Effect of Periodontal Biotype on Inter-Dental Papilla Proportions, Distances Between Facial and Palatal Papillae in the Maxillary Anterior Dentition", J Prosthodont, pp. 517-522, 2017.

[48] PLESSAS, A., ROBERTSON, D.P., HODGE, P.J., "Radiographic bone loss in a Scottish non-smoking Type 1 Diabetes mellitus population; a Bitewing Radiographic Study”, J Periodontol, pp.1043-1051, 2018. [49] STACKHOUSE J.R. JA., "The accuracy of stones die made from rubber impression materials", J Prosthet Dent, v. 24, pp. 377-386, 1970.

[50] GIORDANO, R2ND., "Impression materials: basic properties”, Gen Dent, v. 48, pp. 510-512,514,516, 2000. 
[51] REISBICK, M.H., "Effect of viscosity on the accuracy and stability of elastic impression materials", J Dent Res, v. 52, pp. 407-417, 1973.

[52] SEDDA, M., CASAROTTO, A., RAUSTIA, A., "Effect of storage time on the accuracy of casts made from different irreversible hydrocolloids", J Contemp Dent Pract, v. 9, pp. 59-66, 2008.

[53] GUIRALDO, R.D., MORETI, A.F., MARTINELLI, J., "Influence of alginate impression materials and storage time on surface detail reproduction and dimensional accuracy of stone models", Acta Odontol Latinoam, v. 28, pp. 156-161, 2015.

[54] GÜMÜS, H.O., DINÇEL, M., BÜYÜK, S.K., "The effect of pouring time on the dimensional stability of casts made from conventional and extended-pour irreversible hydrocolloids by 3D modelling", J Dent Sci, v. 10, pp. 275-281, 2015.

[55] FARLEY, N.E., KENNEDY, K., MCGLUMPHY, E.A., "Split-mouth comparison of the accuracy of computer-generated and conventional surgical guides", Int J Oral Maxillofac Implants, v.28, pp. 563-572, 2013.

[56] MEDINA, P., PASCUAL-MOSCARDÓ, A., CAMPS, I., "Relationship between resolution and accuracy of four intraoral scanners in complete-arch impressions", J Clin Exp Dent, v.10, pp. e361-e366, 2018.

[57] PENG, L., CHEN, L., HARRIS, B.T., "Accuracy and reproducibility of virtual edentulous casts created by laboratory impression scan protocols", J Prosthet Dent, pp. 389-395, 2018.

\section{ORCID}

Adriano Relvas Barreira de Oliveira Mário Alexandre Coelho Sinhoreti Marina Amaral Laís Regiane da Silva Concílio Rafael Pino Vitti https://orcid.org/0000-0002-4822-9088

https://orcid.org/0000-0002-1932-2902

https://orcid.org/0000-0002-4301-2760

https://orcid.org/0000-0002-3054-3810

https://orcid.org/0000-0001-6366-5868 